\title{
Analisis Kemampuan Berpikir Kritis (Critical Thingking) Siswa Melalui Penggunaan Soal HOTS Dalam Pembelajaran Bahasa Indonesia
}

\author{
Oktaviandi Bertua Pardede1, Elia Ananda Sinaga ${ }^{2}$, Ari Wina Br Depari ${ }^{3}$, \\ Rumiris Julianti B Gultom ${ }^{4}$ \\ Email: oktaviandibertuapardede@unprimdn.ac.id, eliaananda00@gmail.com, \\ ariwina98@gmail.com, rumirisjulianti@gmail.com \\ Universitas Prima Indonesia
}

\begin{abstract}
Abstrak
Penelitian ini bertujuan untuk mengetahui pengaruh kemampuan awal matematis siswa terhadap penyelesaian soal-soal high order thinking yang ditinjau dari soal analisis, soal evaluasi dan secara umum. Penelitian ini pun bertujuan untuk mengetahui kemampuan siswa dalam menyelesaikan soal-soal high order thinking serta untuk mengetahui faktor-faktor yang menyebabkan siswa keliru dalam menyelesaikan soal-soal high order thinking. Penyempurnaan lainnya juga dapat dilakukan pada standar penilaian, dengan cara mengadaptasi secara bertahap melalui model-model penilaian standar internasional. Penilaian hasil belajar diharapkan dapat membantu para peserta didik untuk lebih meningkatkan kemampuan berpikir tingkat tinggi Higher Order Thinking Skills (HOTS). Karena melalui berpikir tingkat tinggi dapat mendorong peserta didik untuk dapat berpikir secara luas dan lebih mendalam mengenai materi pelajaran. Metode penelitian yang digunakan adalah metode Kualitatif dengan menggunakan model pembelajaran Kooperatif. Adapun tujuan dari model pembelajaran Kooperatif adalah untuk memberikan siswa pengetahuan, konsep, kemampuan, dan pemahaman yang mereka butuhkan supaya dapat bisa menjadi seorang anggota masyarakat yang bahagia dan dapat memberikan kontribusi. Dari hasil penelitian diperoleh bahwa terdapat pengaruh kemampuan awal matematis siswa terhadap penyelesaian soal high order thinking dalam segala aspek. Siswa dikategorikan mampu menyelesaikan soal-soal high order thinking. Aktivitas belajar siswa dan kemampuan berpikir kritis siswa masing-masing masih menunjukkan adanya ketidakseimbangan walaupun guru sudah mengoptimalkan fungsi perangkat pembelajaran dalam pengajarannya.
\end{abstract}

Kata kunci: Berpikir kritis, metode kualitatif, Higher Order Thinking Skills (HOTS)

\section{A. PENDAHULUAN}

Kualitas pendidikan saat ini sudah menjadi masalah yang sudah ada sejak dulu, yang senantiasa diupayakan peningkatannya oleh Pemerintah. Pengendalian mutu pendidikan pada dasarnya merupakan pengendalian mutu SDM (sumber daya manusia) yang telah berada dalam sistem tersebut. Untuk mengetahui pengendalian ini sangat dibutuhkan informasi mengenai keadaan setiap para peserta didik, apakah ada perubahan, apakah guru berfungsi, apakah sekolah sangat mendukung dalam terlaksananya program-program pendidikan sehingga hasilnya dapat dicapai secara optimal. Namun, berdasarkan kenyataan yang sedang terjadi saat ini adalah banyak lembaga pendidikan yang masih menggunakan model pembelajaran sederhana sehingga siswa hanya dituntut untuk menghafalkan. Sedangkan 
kemampuan berpikir tingkat tinggi tidak dibangun dengan baik sehingga hampir semua materi yang diberikan oleh guru hanya diterima begitu saja oleh siswa tanpa adanya tindakan kritis saat dalam proses pembelajaran.

Terkait dengan isu perkembangan pendidikan ditingkat internasional, Kurikulum 2013 dirancang dengan berbagai penyempurnaan. Penyempurnaan tersebut antara lain dilakukan pada standar isi yaitu mengurangi materi yang tidak relevan serta pendalaman dan perluasan materi yang relevan bagi peserta didik yang diperkaya dengan memenuhi kebutuhan peserta didik untuk dapat berpikir kritis dan analitis sesuai dengan standar internasional. Penyempurnaan lainnya juga dapat dilakukan pada standar penilaian, dengan cara mengadaptasi secara bertahap melalui model-model penilaian standar internasional. Penilaian hasil belajar diharapkan dapat membantu para peserta didik untuk lebih meningkatkan kemampuan berpikir tingkat tinggi (Higher Order Thinking Skills/HOTS), karena melalui berpikir tingkat tinggi dapat mendorong peserta didik untuk dapat berpikir secara luas dan lebih mendalam mengenai materi pelajaran (Widana, 2017: 1). Oleh sebab itu, hal ini sepenuhnya merupakan hak dan kewajiban guru dalam mengemban kinerja profesinya. Sehingga kompetensi guru akan lebih optimal dengan adanya perangkat pembelajaran itu. Hal ini diperkuat ketika peneliti mewawancarai Ibu Debora Ginting, S.Pd. selaku guru bidang studi Bahasa Indonesia di SMP Talitakum yang merupakan lokasi penelitian ini. Secara terperinci setiap narasumber menjelaskan bahwa siswa masih belum memiliki kemampuan berpikir kritis, hal ini dapat diyakini dari hasil ulangan siswa yang masih rendah yaitu dibawah KKM 70. Peneliti juga memperoleh bahwa guru selalu menyusun soal sendiri, sehingga instrument yang digunakan semakin menunjang terhadap materi yang sudah dipelajari. Selain itu, peneliti juga mengamati kegiatan belajar siswa di kelas dan diketahui bahwa beberapa guru sudah menerapkan model pembelajaran diskusi dan sebagian besar lainnya mengajar secara konvensional (ceramah).

Berdasarkan hasil studi di atas dapat digambarkan bahwa kemampuan berpikir kritis siswa perlu ditingkatkan untuk memenuhi kebutuhan kurikulum saat ini yang semakin kompleks. Soal bahasa Indonesia yang digunakan oleh guru didominasi oleh soal kompleks, sehingga soal yang diberikan mengarah pada kebutuhan berpikir kritis. Hal ini perlu dioptimalkan karena sumber belajar yang digunakan pada kurikulum saat ini menuntut siswa untuk memiliki kompetensi yang kompleks, mulai dari aktivitas belajar hingga cara berpikir siswa. Model pembelajaran juga memiliki kaitan yang signifikan dalam mengoptimalkan proses berpikir siswa. Oleh sebab itu, untuk lebih mengoptimalkan kemampuan berpikir kritis 
siswa, maka peneliti akan menggunakan model pembelajaran yang relevan untuk lebih menigkatkan kemampuan berpikir kritis dalam penelitian ini.

Pembelajaran Bahasa Indonesia yang berlangsung di dalam kelas sangat disesuaikan dengan perkembangan zaman. Peserta didik selalu diberi materi atau soal-soal yang berintegrasi dengan kehidupan sehari-hari, dan hal itu sesuai dalam kurikulum 2013 revisi 2017, pembelajaran Bahasa Indonesia wajib menerapkan proses berpikir tingkat tinggi atau HOTS untuk meningkatkan daya pikir peserta didik. Dalam pengembangan HOTS diperlukan kemampuan pendidik untuk merencanakan dan mengelola pembelajaran yang efektif dalam membelajarkan peserta didik, baik dalam berpikir secara logis, sikap, maupun keterampilan. Persiapan tersebut dapat disusun dengan perangkat pembelajaran. Namun, faktanya guruguru atau pengajar di Indonesia belum bisa membiasakan diri dan mengenalkan peserta didik dengan soal-soal HOTS. Hal ini dapat dibuktikan dengan pembelajaran yang didominasi dengan soal-soal berbasis HOTS. Peran guru sangat penting dalam menjadikan peserta didik memiliki kemampuan berpikir tingkat tinggi. Oleh karena itu, guru harus lebih mampu lagi untuk memberikan soal-soal yang berkaitan dengan kehidupan sehari-hari. Agar semakin lebih menarik dan semakin melatih siswa untuk mengembangkan kemampuannya dalam berpikir.

Berpikir aras tinggi merupakan suatu aktivitas mental atau kognisi yang mencakup tiga kemampuan, yaitu menganalisis, mengevaluasi dan mencipta (Anderson dan Krathwohl 2001). Pembelajaran Bahasa Indonesia berbasis BAT memiliki makna bahwa belajar Bahasa Indonesia dengan melibatkan ketiga kemampuan mental itu. Dalam konteks pengajaran, Bloom (1984) mengemukakan ada enam tingkat cara berpikir, yaitu: mengingat (remember), memahami (understand), menggunakan (apply), menganalisis (analyze), mensintesis (synthesize) dan mengevaluasi (evaluate). Keenam tingkat berpikir atau kognisi tersebut menunjukkan bahwa aktivitas mental dari tingkat yang rendah sampai ke tingkat tertinggi, kemudian dari tingkat yang mudah ke tingkat yang sukar, atau dari tingkat yang sederhana ke tingkat yang kompleks atau rumit. Para guru dapat menggunakan taksanomi Bloom ini untuk menyusun kurikulum pembelajaran bahasa.

Pembelajaran tentang Teks Ulasan dan Teks Persuasi di sekolah merupakan sarana yang potensial untuk meningkatkan HOTS. Sebagai sebuah karya yang kreatif, sastra dapat memicu keterlibatan pikiran dan perasaan siswa dalam suasana yang kreatif. Penggunaan bahasa yang berbeda dan ide-ide yang luar biasa, serta lompatan-lompatan pikiran dari seorang pengarang dapat dijadikan bahan untuk memperkaya suatu keterampilan berbahasa siswa dan dapat lebih kritis terhadap sebuah sastra. Di dalam K-13, Pembelajaran bahasa 
Indonesia dianjurkan Berbasis Teks (PBT), yaitu suatu pendekatan pengajaran berbahasa yang menjadikan teks (tulis atau lisan) sebagai awal dan akhir pembelajaran. Siswa membaca teks, menganalisis teks, lalu membuat teks. Pembelajaran sastra Indonesia merupakan suatu bagian yang tidak dapat terpisahkan dari keterampilan berbahasa Indonesia lainnya. Belajar bahasa Indonesia di sekolah ditekankan bagaimana siswa dapat lebih kritis terhadap sebuah karya sastra, yaitu untuk menumbuhkan rasa lebih menghargai terhadap cipta sastra sebagai salah satu bentuk pengungkapan ide (salah satu jenis teks). Pada akhirnya siswa diharapkan mampu mengungkapkan ide-idenya dalam bentuk cipta sastra atau bahasan terhadap cipta sastra. (Atmazaki, 2016).

Model pembelajaran kooperatif adalah suatu metode kegiatan belajar yang dilakukan dengan cara mengelompokkan para siswa kedalam sebuah kelompok kecil, yang bertujuan untuk mencapai tujuan pembelajaran yang telah dirumuskan. Pembelajaran kooperatif adalah model pembelajaran yang lebih berfokus terhadap penggunaan kelompok kecil siswa untuk bekerja sama guna untuk memaksimalkan kondisi belajar untuk mencapai tujuan belajar (Sugiyanto, 2010: 37). Tujuan dari model pembelajaran Kooperatif adalah menyampaikan tujuan yang paling penting dari model pembelajaran kooperatif. Maka dapat disimpulkan bahwa tujuannya adalah untuk memberikan siswa pengetahuan, konsep, kemampuan, dan pemahaman yang mereka butuhkan supaya dapat bisa menjadi seorang anggota masyarakat yang bahagia dan dapat memberikan kontribusi, Slavin (2005)Dapat ditemui beberapa masalah yang menyangkut tentang berkembangnnya soal HOTS dikalangan Sekolah Menengah Pertama (SMP) yang terjadi dalam pelaksanaan kegiatan pembelajaran di kelas. Namun yang lebih difokuskan adalah tentang pengaruhnya soal HOTS dalam pelajaran Bahasa Indonesia dikalangan SMP, yang dimana para siswa diajak untuk berpikir kritis serta berpikir kreatif untuk mengembangkan pola piker mereka dalam pelajaran Bahasa Indonesia.

Guru juga dapat mempelajari berbagai strategi menggunakan soal HOTS melalui banyak sumber. Salah satu contoh, Cardellichio dan Field (1997) memaparkan tujuh strategi untuk memperluas jaringan saraf anak untuk meningkatkan kemampuan HOTS secara umum. Ketujuh teknik itu adalah berpikir hipotetis, berpikir kebalikan (pembalikan), penerapan sistem simbol yang berbeda, analogi, analisis sudut pandang, penyelesaian, dan analisis jaringan.

Berdasarkan uraian di atas, peneliti terdorong untuk mengetahui lebih lanjut mengenai penerapan keterampilan berpikir tingkat tinggi atau HOTS di kelas VII pada salah satu SMP Swasta di Medan. Penelitian ini tidak hanya dilakukan pada proses pembelajaran tetapi juga pada rencana pelaksanaan pembelajaran (RPP) dan soal evaluasi yang disusun oleh guru dan 
peneliti. Melalui penelitian ini, diharapkan banyak pihak terutama dalam bidang pendidikan mengetahui seberapa jauh penerapan keterampilan berpikir tingkat tinggi di Sekolah Menengah Atas (SMP) dalam menjawab soal Bahasa Indonesia, sehingga pihak terkait bisa mengambil langkah lebih lanjut terhadap kenyataan penerapan keterampilan berpikir tingkat tinggi yang ada di lapangan. Oleh karena itu, peneliti memutuskan untuk melakukan penelitian dengan judul "Analisis Kemampuan Berpikir Kritis (Critical Thingking) Siswa Melalui Penggunaan Soal Hots Dalam Pembelajaran Bahasa Indonesia”.

\section{B. KAJIAN TEORI}

\section{Berpikir Aras Tinggi}

Berpikir aras tinggi merupakan suatu aktivitas mental atau kognisi yang mencakup tiga kemampuan, yaitu menganalisis, mengevaluasi dan mencipta (Anderson dan Krathwohl 2001). Pembelajaran Bahasa Indonesia berbasis BAT memiliki makna bahwa belajar Bahasa Indonesia dengan melibatkan ketiga kemampuan mental itu. Dalam konteks pengajaran, Bloom (1984) mengemukakan ada enam tingkat cara berpikir, yaitu: mengingat (remember), memahami (understand), menggunakan (apply), menganalisis (analyze), mensintesis (synthesize) dan mengevaluasi (evaluate). Keenam tingkat berpikir atau kognisi tersebut menunjukkan bahwa aktivitas mental dari tingkat yang rendah sampai ke tingkat tertinggi, kemudian dari tingkat yang mudah ke tingkat yang sukar, atau dari tingkat yang sederhana ke tingkat yang kompleks atau rumit. Para guru dapat menggunakan taksanomi Bloom ini untuk menyusun kurikulum pembelajaran bahasa.

\section{METODE PENELITIAN}

Lokasi tempat dilaksanakannya penelitian adalah SMP Talitakum di Kecamatan Medan Petisah. Periode pelaksanaan penelitian ini direncanakan selesai dalam 3 bulan (mulai Maret 2020 - Mei 2020). Adapun populasi penelitian ini adalah siswa SMP kelas VIII dengan jumlah siswa 25 orang. Berdasarkan data siswa di atas, maka jumlah sampel tersebut akan digunakan seluruhnya. Menurut Sugiyono (2017), metode penelitian kualitatif merupakan sebuah metode penelitian yang berlandaskan pada filsafat postpositivisme, yang digunakan untuk meneliti pada kondisi objek yang alamiah atau lawannya adalah eskperimen, yang dimana peneliti merupakan sebuah instrument kunci, teknik pengumpulan data dilakukan secara triangulasi (gabungan), analisis data bersifat induktif/kualitatif, dan hasil penelitian kualitatif lebih menekankan makna dari pada generalisasi bahwa sampel diambil berdasarkan tujuan penelitian sehingga peneliti menggunakan seluruh siswa di kelas VIII sebagai objek 
penelitian. Teknik penarikan sampel ini pada dasarnya memperhatikan kebutuhan penelitian dan didasarkan pada arahan para ahli (dosen).

Adapun variabel dalam penelitian ini adalah model pembelajaran kooperatif, keterampilan berpikir kritis, dan soal HOTS pada pelajaran bahasa Indonesia. Penelitian ini melibatkan satu kelas yaitu kelas VIII. Adapun penelitian ini menggunakan pendekatan penelitian deskriptif kualitatif. Desain penelitian ini menggunakan alur yang disesuaikan dengan aktivitas penelitian yaitu dimulai dari pembuatan soal, pembelajaran secara kooperatif dalam meningkatkan kemampuan berpikir kritis siswa dan pengadaan evaluasi dengan menggunakan soal HOTS. Selanjutnya peneliti akan yang akan mengintegrasikan komponenkomponen penelitian, sehingga peneliti dapat menyimpulkan hasil penelitian.

Adapun prosedur-prosedur yang dilaksanakan dalam penelitian ini, ditempuh langkahlangkah sebagai berikut :

1. Tahap persiapan

Kegiatan yang akan dilakukan didalam tahap ini ialah meliputi persiapan-persiapan yang sehubungan dengan pelaksanaan penelitian.

- Konsultasi dengan kepala sekolah SMP Talitakum Medan untuk memohon izin untuk melakukan penelitian.

- Menyusun kegiatan rencana pembelajaran sebagai panduan penelitian dalam proses pencapaian tujuan yang diinginkan.

- Menyusun instrumen untuk memperoleh data tentang hasil belajar siswa.

2. Tahap pelaksanaan

- Menentukan kelas sampel dari populasi yang ada.

- Melaksanakan penyesuaian alur penelitian dengan aktivitas mengajar guru di sekolah.

- Mempersiapkan materi yang direncanakan, yaitu materi memahami teks berita.

- Mengajarkan materi pelajaran dengan menggunakan model pembelajaran koopertaif.

- Memberikan pertanyaan yang dapat menstimulus keterampilan berpikir kritsi siswa.

3. Tahap pengumpulan data

Data dalam penelitian ini dapat dikumpulkan setelah tes diberikan pada siswa, kemudian dilakukan penskoran. Berikut tahapan pengelolaan datanya:

- Mentabulasikan data yang berhubungan dengan variable yang diteliti. 
- Mengolah data hasil penelitian berdasarkan instrument yang digunakan.

- Mendeskripsikan hasil penelitian untuk selanjutnya akan dibahas pada laporan penelitian.

Adapun alat pengumpul data dalam penelitian ini digunakan tes bentuk pilihan berganda sebanyak 20 soal. Sebelum soal tersebut digunakan sebagai alat pengumpul data terlebih dahulu divalidasi oleh validator/ para ahli yang bertujuan untuk mengetahui kelayakan instrument. Kriteria penilaian soal pilihan ganda yang dijawab benar dengan skor 1 dan salah skor 0 Selanjutnya jumlah total skor dari setiap siswa dikonversikan ke dalam bentuk nilai dengan menggunakan rumus sebagai berikut:

$$
\text { Nilai }=\frac{\text { Jumlahskor yang diperoleh }}{\text { Jumlah skor maksimum }} \times 100
$$

Untuk mengetahui kategori kemampuan siswa, maka terlebih dahulu menentukan kriteria yang akan dijadikan dasar untuk mengambil kesimpulan seperti yang ada pada tabel berikut ini:

Tabel 2.4. Kategori Kemampuan Siswa

\begin{tabular}{|l|l|}
\hline Interval & Kriteria \\
\hline $80-100$ & Baik sekali \\
\hline $60-79$ & Baik \\
\hline $40-59$ & Cukup \\
\hline $30-49$ & Kurang \\
\hline $0-29$ & Gagal \\
\hline
\end{tabular}

Selanjutnya penelitian ini juga menggunakan data pengamatan untuk mengetahui keterampilan berpikir kritis siswa. Peneliti akan menerapkan model pembelajaran yang dipilih dan mengikuti tahapan model tersebut. Oleh sebab itu, aktivitas belajar siswa akan didokumentasikan sebagai bentuk pengamatan penelitian.

Teknik analitis data yang digunakan adalah teknik analisis deskriptif kualitatif. Penelitian kualitatif adalah penelitian yang digunakan untuk memperoleh data hasil penelitian dari data primer dan sekunder, artinya penelitian akan menemukan, mereduksi dan menyimpulkan komponen-komponen yang saling memiliki keterkaitan untuk mencapai tujuan penelitian ini. Teknik ini akan menggambarkan data-data hasil penelitian berdasarkan instrument yang telah ditentukan. Selanjutnya data hasil penelitian akan diolah sesuai dengan instrument penelitian. Berdasarkan instrument yang telah ditentukan maka angket akan dianalisis dengan memedomani kriteria berikut ini: 


\begin{tabular}{|c|c|c|}
\hline Kriteria & Positif & Negatif \\
\hline Sangat setuju & 7 & 2 \\
\hline Setuju & 5 & 1 \\
\hline Ragu-ragu & 3 & 1 \\
\hline Tidak setuju & 1 & 2 \\
\hline Sangat tidak setuju & 1 & 2 \\
\hline
\end{tabular}

Selanjutnya, untuk wawancara yang dilakukan peneliti akan memberikan beberapa pertanyaan kepada guru, yang nantinya akan dilakukan penelitian serta observasi yang akan disesuaikan menurut kriteria variable penelitian seperti penggunaan RPP, penggunaan media pembelajaran, hasil belajar siswa dalam beberapa tahun yang lewat, fasilitas belajar, serta aktivitas siswa selama disekolah. Sehingga 4 butir wawancara dan observasi akan terpenuhi setelah peneliti melakukan telaah bersama dengan guru dan dosen pembimbing. Peneliti juga akan membuat tes pilihan ganda dengan menyusun kisi-kisi terlebih dahulu, yaitu sesuai dengan materi yang sedang diajar oleh guru, tingkat kesukaran soal, hingga ke validan soal. Maka, peneliti akan berkonsultasi dengan dosen ahli pendidikan bahasa dan sastra Indonesia. Dan soal yang telah direvisi akan digunakan dalam pengambilan data. Dengan demikian penelitian ini akan lebih mengutamakan hasil setiap instrument terlebih dahulu dan untuk sela njutnya peneliti akan menganalisisnya berdasarkan teknik analisis kualitatif.

\section{HASIL DAN PEMBAHASAN PENELITIAN}

\subsection{HASIL PENELITIAN}

\section{A. Deskripsi Hasil Penelitian}

Berdasarkan metode penelitian yang telah disusun, maka data yang perlu dideskripsikan pertama sekali pada bab ini yaitu tentang kevalid-an instrument penelitian. Seperti pada angket penelitian ini menggunakan pertanyaan tertulis yang dijawab secara tertulis oleh sampel penelitian. Kemudian soal/tes objektif dengan menggunakan pertanyaan dengan 4 pilihan jawaban yang dipilih pada lembar jawaban (google form). Kedua instrumen penelitian ini sudah ditelaah oleh para ahli yaitu Bapak Syahrizal Akbar, S.Pd., M.Pd. yang merupakan salah satu dosen dari Prodi Bahasa Indonesia di Universita Prima Medan. Hasilnya diketahui bahwa kedua instrumen tes dan angket dalam penelitian ini layak digunakan untuk mengumpulkan data penelitian. Sedangkan instrumen observasi penelitian disesuaikan 
dengan identifikasi masalah dan tujuan penelitian ini. Oleh karena itu, peneliti menyusun observasi penelitian dengan indikator yang dapat diinderawi secara langsung.

Para ahli dalam penelitian ini telah memberikan hasil analisisnya dalam bentuk validasi secara isi dan dapat dibuktikan melalui lembar persetujuan pada lampiran. Karena tim peneliti telah mendapatkan butir-butir instrumen yang valid dan reliabel maka selanjutnya akan dideskripsikan beberapa komponen hasil penelitian.

Dengan demikian seluruh butir indikator instrument akan dideskripsikan sesuai dengan kebutuhan analisis data dan tujuan penelitian. Selanjutnya, data penelitian secara berturutturut akan dijelaskan mulai dari subjek penelitian, hasil tes, dan angket hingga pada hasil observasi penelitian.

\section{B. Deskripsi Subjek Penelitian}

Teknik penarikan sampel yang digunakan adalah satu sekolah dengan jumlah total 25 siswa. Subjek penelitian juga diarahkan pada sarana dan prasarana yang terdapat pada masing-masing sekolah. Berdasarkan peninjauan selama penelitian dapat diklasifikasikan beberapa sarana dan prasarana yang terdapat di sekolah yaitu:

Tabel 3.1 Sarana dan Prasarana Sekolah

\begin{tabular}{|c|l|c|}
\hline No & \multicolumn{1}{|c|}{ Kriteria } & Keterangan \\
\hline 1. & Ruang Guru & Baik \\
\hline 2. & Ruang Belajar & Baik \\
\hline 3. & Ruang Kepala Sekolah & Baik \\
\hline 4. & Ruang Perpustakaan & Cukup \\
\hline 5. & Lapangan Sekolah & Baik \\
\hline 6. & Jumlah Siswa & 25 \\
\hline 7. & Jumlah Guru & 9 \\
\hline 8. & Jumlah Pegawai & - \\
\hline
\end{tabular}

Adapun tujuan dideskripsikan perbandingan siswa serta sarana dan prasarana sekolah adalah sebagai upaya dalam pendukung komponen-komponen yang akan digunakan dalam analisis data terkait penentuan strategi yang digunakan dalam penelitian ini.

Tabel di atas merupakan sebuah deskripsikan mengenai kondisi sekolah yang digunakan sebagai pendukung analisis data terkait dengan tujuan penelitian ini, terutama pada analisis data instrument observasi yang digunakan. Oleh karena itu, berdasarkan data tabel diatas dapat diketahui bahwa kondisi sekolah ini termasuk kategori "baik". Demikian juga perbandingan tenaga kerjanya juga sebanding dengan jumlah siswa dan ruangan yang 
dikelola oleh sekolah, sehingga aktivitas belajar dan mengajar sekaligus operasional sekolah dilaksanakan secara optimal.

\section{Deskripsi Perangkat Pembelajaran}

Perangkat pembelajaran yang digunakan dalam penelitian ini berupa Rencana Pelaksaan Pembelajaran (RPP), buku materi, dan alat pendukung pembelajaran lainnya yang digunakan sebagai acuan dalam proses pembelajaran di kelas. Sesuai dengan road map penelitian bahwa garis besar penelitian ini akan memperhatikan pengadaan RPP yang sesuai dengan standar kurikulum yang berlaku dan penelitian ini juga mendeskripsikan tentang penggunaan media pembelajaran (termasuk buku pelajaran dan sejenisnya) melalui pengamatan dan wawancara dengan guru bersama pihak sekolah.

Hasil penelitian ini menunjukkan bahwa RPP pelajaran Bahasa Indonesia yang digunakan telah mengacu pada standar kurikulum 2013 revisi 2017. Guru sudah menyusun setiap materi ajar beserta aktivitas belajar dalam RPP secara komprehensif dan terintegrasi. Namun, di masa pandemic covid-19 aktivitas belajar dirancang kembali dengan memanfaatkan laman website seperti google meet, google classroom, zoom meeting, dll. Serta juga menggunakan aplikasi berbasis social media seperti whatsapp, Facebook, LINE, dll.

\section{Deskripsi Hasil Tes}

Berdasarkan tabel di atas, pemerolehan nilai dari setiap siswa diakumulasikan secara merata dan secara rasio terdapat perbedaan nilai antar siswa. Namun pada tabel hasil tes kemampuan siswa ditemukan bahwa kemampuan berpikir kritis setiap siswa kelas VIII di SMP TALITAKUM memiliki nilai rata-rata yang standart.

Instrumen tes yang digunakan dalam penelitian ini bertujuan untuk mengetahui prestasi belajar siswa terhadap materi yang diajarkan oleh guru. Terkait dengan materi bahan ajar yang diuji dalam penelitian ini, maka guru sudah menjelaskannya sesuai dengan RPP yang disusun berdasarkan kurikulum yang berlaku. Bahan ajar yang diberikan juga relevan dengan isi pertanyaan tes sehingga pertanyaan butir soal hanya berisi materi yang pernah dijelaskan oleh guru. Peneliti juga telah menyusun 20 butir soal pilihan ganda dan hasilnya diperoleh sebagai berikut: 


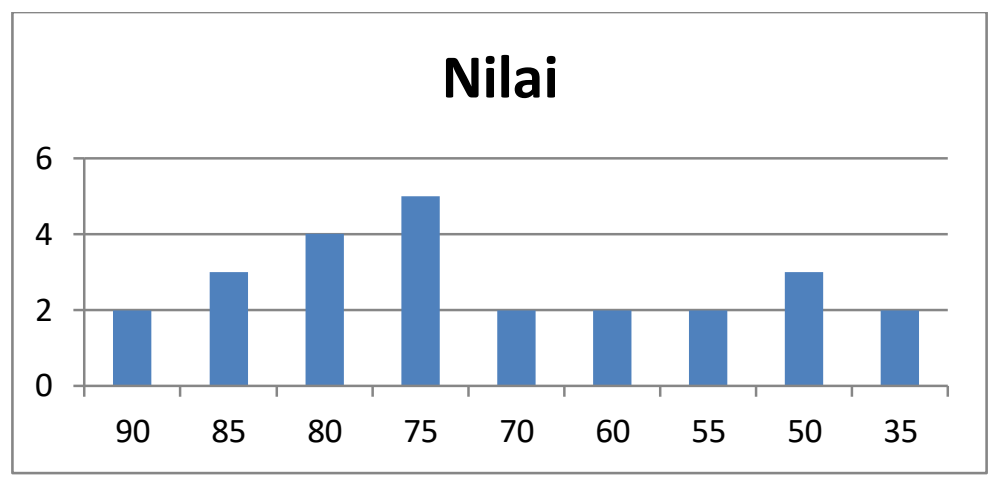

Gambar 3.1. Hasil Tes Pilihan Ganda

Berdasarkan hasil tes, dapat diketahui bahwa 36\% siswa nilainya di bawah KKM dan sekitar 64\% siswa nilainya diatas KKM. Hasil ini juga menunjukkan bahwa hasil belajar kelas ini baik, mengingat Kriteria Ketuntasan Minimal (KKM) Bahasa Indonesia yang digunakan oleh guru adalah 70. Jadi berdasarkan data tes ini dapat diketahui bahwa terdapat 9 siswa yang tidak mencapai KKM dan 16 siswa yang mencapai KKM.

\section{E. Deskripsi Hasil Angket}

Penyususnan angket dijabarkan melalui beberapa indikator kemudian dirincikan menjadi butir-butir pertanyaan. Angket ini terdiri dari 15 butir pertanyaan dengan 5 pilihan jawaban ordinal (sangat setuju, setuju, ragu- ragu, tidak setuju, dan sangat tidak setuju). Berikut hasil angket yang telah diteliti.

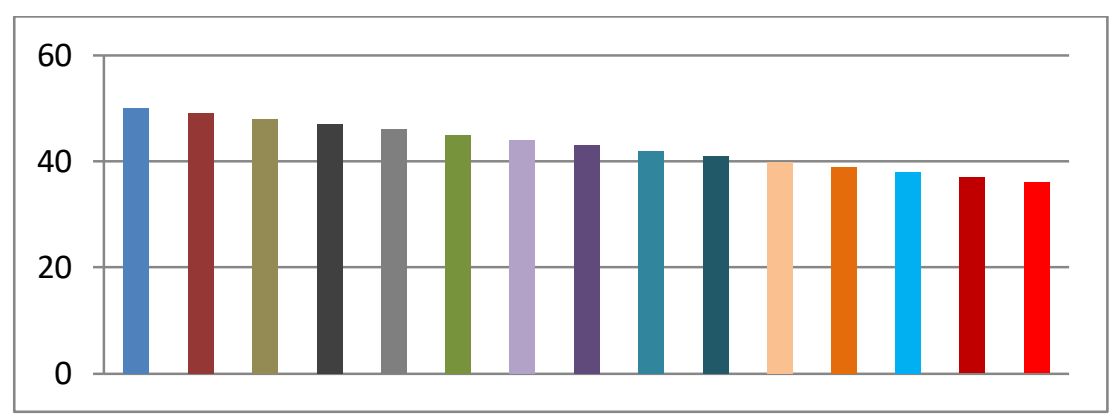

\section{Gambar 3.2. Hasil Angket}

Indikator 1 : Pembelajaran yang di terapkan guru sudah merangsang kemampuan berpikir kritis saya.

Indikator 2 : Keterampilan berpikir kritis dapat mengembangkan daya nalar untuk membantu saya dalam memecahkan masalah.

Indikator 3 : Keterampilan berpikir kritis kurang bermanfaat bagi kehidupan saya.

Indikator 4 : Saya menyadari pentingnya kemampuan berpikir kritis.

Indikator 5 : Akan semakin sulit memecahkan masalah setelah belajar mengembangkan keterampilan berpikir kritis.

Indikator 6 : Berfikir kritis sangat bermanfaat sebagai bekal saya untuk menghadapi masa 
depan.

Indikator 7 : Kemampuan berpikir kritis saya tidak dapat ditingkatkan melalui pembahasan soal-soal HOTS.

Indikator 8 : Guru sangat berperan penting dalam peningkatan kemampuan berpikir kritis saya.

Indikator 9 : Pola pikir saya sudah jauh berubah ke arah yang lebih positif setelah belajar berpikir kritis.

Indikator 10 : Seseorang yang memiliki kemampuan berpikir kritis akan semakin sulit untuk mengikuti pelajaran di sekolah.

Indikator 11 : Kegiatan yang dapat mengembangkan keterampilan berpikir kritis saya adalah dengan aktif menjawab pertanyaan-pertanyaan kuis di sekolah.

Indikator 12 : Belajar berpikir kritis adalah salah satu persiapan saya dalam pemecah masalah yang tangguh.

Indikator 13 : Kemampuan berpikir kritis sangat di perlukan dalam segala bidang ilmu.

Indikator 14 : Kemampuan berpikir kritis tidak hanya diperlukan saat belajar tetapi juga diperlukan ditengah masyarakat.

Indikator 15 : Kemampuan berpikir kritis mempermudah saya dalam mengulas permasalahan pembelajaran.

Berdasarkan hasil di atas dapat diketahui bahwa sebesar 36\% siswa kurang menyadari pentingnya berpikir kritis dalam mengikuti pelajaran Bahasa Indonesia. Hal ini menunjukkan bahwa aktivitas belajar siswa akan semakin kondusif jika guru mengajar sesuai dengan RPP (perangkat pembejaran). Hasil angket juga menunjukkan bahwa hanya 64\% siswa yang menyadari pentingnya berpikir kritis selama mengikuti aktivitas belajar yang diselenggarakan oleh guru. Maka, dengan demikian dapat diketahui bahwa aktivitas belajar siswa semakin optimal dengan adanya pengajaran yang disusun dalam perangkat pembelajaran.

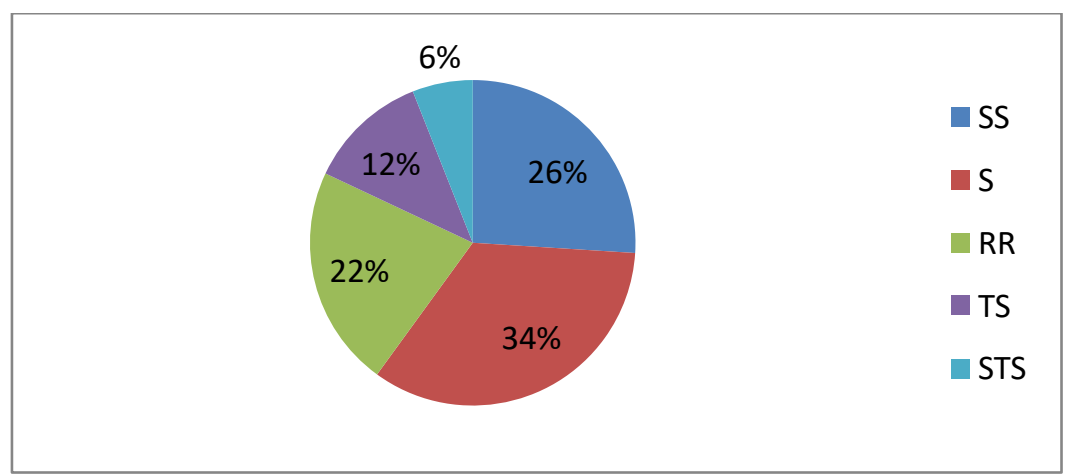

Gambar 3.3. Persentase Pilihan Angket 


\section{F. Deskripsi Hasil Observasi}

Pelaksanaan observasi yang telah dilakukan selama 3 bulan bersamaan dengan instrumen penelitian lainnya. Adapun observasi penelitian ini dilakukan untuk menjaga objektivitas penilaian terhadap sekolah dan integrasi tujuan penelitian, selanjutnya berikut ini hasil observasi yang telah diperoleh.

Tabel 3.2. Hasil Observasi Penelitian

\begin{tabular}{|l|c|c|c|c|}
\hline \multirow{2}{*}{ Indikator } & \multicolumn{2}{|c|}{ Jumlah Teramati } & \multicolumn{2}{c|}{ Persen Pengamatan } \\
\cline { 2 - 5 } & Tampak & Tidak tampak & Tampak & Tidak tampak \\
\hline $\begin{array}{l}\text { Siswa tidak bersemangat dalam } \\
\text { mengerjakan tugas. }\end{array}$ & 13 & 12 & $52 \%$ & $48 \%$ \\
\hline $\begin{array}{l}\text { Siswa pasif, tidak berinteraksi dan tidak } \\
\text { inisiatif mengenai masalah yang diteliti } \\
\text { terkait dengan berpikir kritis. }\end{array}$ & 10 & 15 & $40 \%$ & $60 \%$ \\
\hline $\begin{array}{l}\text { Siswa bersemangat mengerjakan tes } \\
\text { dan seluruh aktivitas belajar }\end{array}$ & 16 & 9 & $70 \%$ & $30 \%$ \\
\hline Siswa aktif selama kegiatan penelitian & 15 & 10 & $60 \%$ & $40 \%$ \\
\hline $\begin{array}{l}\text { Siswa mampu berpikir kritis selama } \\
\text { penelitian melalui pembelajaran Daring }\end{array}$ & 14 & 11 & $56 \%$ & $44 \%$ \\
\hline $\begin{array}{l}\text { Banyak lomba atau kreativitas yang } \\
\text { terselenggara dan diikuti oleh siswa. }\end{array}$ & 15 & 10 & $60 \%$ & $40 \%$ \\
\hline
\end{tabular}

Berdasarkan tabel di atas dapat diketahui bahwa sebesar 52\% siswa tampak semangat mengerjakan tes dan setiap aktivitas belajar yang disusun oleh guru. Namun pada interaksi belajar dan keinisiatifan mengenai masalah penelitian ini tampak $60 \%$ siswa menunjukkan perilaku yang sesuai dengan tujuan penelitian. Ditambah lagi sekitar 56\% siswa yang mampu berpikir kritis selama pembelajaran daring. Maka, berdasarkan data ini dapat diketahui bahwa aktivitas belajar siswa dan kemampuan berpikir kritis siswa masing-masing masih menunjukkan adanya ketidakseimbangan walaupun guru sudah mengoptimalkan fungsi perangkat pembelajaran dalam pengajarannya.

\subsection{Pembahasan}

Sesuai dengan deskripsi hasil penelitian yang telah dijelaskan, maka dapat diyakini bahwa instrument yang digunakan telah memenuhi kriteria kelayakan. Melalui uji kelayakan (data terlampir) yang dilakukan oleh para ahli maka setiap instrument penelitian ini telah mampu mengukur hasil belajar (prestasi) siswa dengan cara berpikir kritis serta aktivitas belajar siswa melalui penggunaan soal HOTS dalam pembelajaran Bahasa Indonesia. Perangkat pembelajaran yang disusun oleh guru juga menunjukkan efek yang sama terhadap instrument 
yang digunakan dalam penelitian ini. Hal tersebut terlihat jelas dengan serupanya hasil tes, angket dan observasi yang telah diperoleh melalui analisis data penelitian ini.

Pertama, pada hasil tes dapat diketahui bahwa terdapat $36 \%$ siswa yang nilainya berada di bawah KKM dan 64\% siswa yang nilainya mencapai KKM. Substansi materi pertanyaan tes yang diberikan oleh guru sudah dijelaskan secara keseluruhan, kemudian di setiap pertemuan guru selalu memberikan pembelajaran sesuai dengan RPP sekolah. Guru juga sudah memasukkan beberapa pertanyaan yang pernah diberikan ketika pembelajaran normal berlangsung. Tampaknya hasil belajar (prestasi) siswa dapat meningkat dengan adanya penggunaan soal HOTS, guna untuk melatih siswa dalam berpikir kritis.

Tingkat pemahaman siswa yang beragam, kondisi/situasi belajar yang serupa dengan indikator yang dijelaskan pada RPP. Oleh karena itu, dalam kasus ini keterampilan berpikir siswa harus dilakukan setelah semua siswa sudah memiliki pengetahuan yang kuat/jelas tentang tingkat pemahaman siswa mengenai soal-soal berbasis HOTS dan guru juga harus memiliki keterampilan dalam mendiagnosa kemampuan berpikir kritis siswa selama pembelajaran dikelas berlangsung.

Kedua, hasil angket penelitian telah menunjukkan bahwa dari 15 butir pernyataan terdapat 11 indikator pernyataan yang mencapai lebih dari $34 \%$ hasil yang mengarah ke pilihan positif (setuju). Artinya dari sudut pandang siswa, pengajaran yang diberikan oleh guru telah sesuai dengan harapan siswa selama pembelajaran berlangsung. Keterampilan berpikir kritis siswa (seperti RPP dan media pembelajaran) cukup mempengaruhi aktivitas belajarnya selama guru mengajar terutama dalam kehidupan sehari-hari. Siswa juga semakin tahu target pembelajaran dan memahami pola belajar yang dituntut oleh guru secara komprehensif. Tentu saja hasil ini berkaitan dengan hasil belajar siswa yang telah dianalisis sebelumnya. Maka, pengajaran yang dilakukan guru sudah sesuai dengan harapan dan perlu dipertahankan uintuk kedepannya agar hasil belajar siswa semakin meningkat atau mencapai KKM. Oleh sebab itu, berdasarkan kedua hasil instrumen ini tampaknya aktivitas belajar dan prestasi belajar siswa berkaitan langsung terhadap keterammpilan berpikir kritis siswa.

Berdasarkan temuan ini, maka keterampilan berpikir kritis siswa diasumsikan dapat berdampak positif terhadap aktivitas belajar saja dan keberadaannya harus dibarengi dengan faktor lainnya untuk meningkatkan hasil belajar (prestasi) siswa. Peneliti juga melihat adanya pandemic covid-19 memberikan dampak negatif terhadap proses pembelajaran yang telah disusun guru dalam RPP. Siswa menjadi kurang termotivasi serta kurang aktif selama pembelajaran akibat dari sistem pembelajaran jarak jauh (daring dan luring). Terutama peraturan dari pemerintah yang telah menetapkan bahwa semua kegiatan tatap muka atau 
berhadapan langsung dihimbau untuk dilakukan secara online, terutama bagi yang sedang menempuh jenjang pendidikan agar belajar di rumah demi menjaga kesehatan di masa pandemic ini. Jadi, kemungkinan besar rendahnya nilai siswa dalam penelitian ini disebabkan oleh adanya perubahan sistem belajar, dari pembelajaran tatap muka menjadi pembelajaran jarak jauh.

Ketiga, hasil observasi penelitian ini menunjukkan adanya semangat dalam mengerjakan tes dan antusiasme mengikuti pembelajaran secara langsung di kelas. Sebagaimana telah dideskripsikan pada hasil penelitian bahwa persentasenya mencapai 70\%. Data ini tampaknya tidak linier dengan hasil tes, tetapi peneliti yakin bahwa siswa memiliki hasrat untuk mengerjakan tes meskipun pengetahuan siswa tentang materi yang telah dijelaskan cenderung belum tuntas. Hasil observasi juga menunjukkan bahwa terdapat $60 \%$ siswa pernah mengikuti lomba atau kreativitas sekolah, sehingga adanya keterampilan berpikir kritis tampaknya lebih optimal untuk mengembangkan aktivitas belajar siswa dan meningkatkan keterampilan siswa secara afektif.

Berdasarkan temuan ini, peneliti berasumsi bahwa sebagian besar hasil observasi penelitian mengarah pada dampak pengiring lainnya yakni perangkat pembelajaran membuat siswa mampu mengembangkan bakat dan minat lainnya. Penelitian ini juga menunjukkan bahwa hasil belajar (prestasi) siswa harus dieksplorasi dengan berbagai cara dan bukan hanya melalui pengembangan RPP atau media pembelajaran saja. Guru juga harus mampu menerapkan dan mengimprovisasi keterampilan berpikir kritis siswa dengan menggunakan soal-soal yang berbasis HOTS. Jadi, variabel penelitian yang teramati ini memberikan kontribusi dalam profesi guru Bahasa Indonesia, khususnya dalam mengasah keteampilan berpikir kritis siswa sebagai salah satu metode pendukung dalam kurikulum K13.

Dengan terhimpunnya uraian di atas, maka penelitian ini telah menunjukkan bahwa aktivitas belajar dan prestasi belajar dapat ditingkatkan melalui keterampilan berpikir kritis. Pada variabel prestasi belajar, keberadaan perangkat pembelajaran telah signifikan dan perlu dikembangkan kembali oleh guru yang bersangkutan. Karena prestasi belajar sangat berkaitan dengan kemampuan berpikir (aspek kognitif), sehingga guru perlu mendiagnosis kemampuan siswa terlebih dahulu sebelum melakukan pembelajaran yang dirancang dalam RPP. Kemudian pada variabel aktivitas belajar siswa telah menunjukkan hasil yang signifikan. Hasil angket dan observasi secara keseluruhan memberikan kontribusi pada peningkatan afektif dan psikomotorik siswa saja. Aktivitas belajar siswa menjadi teratur dan terarah serta keterampilan siswa lebih berkembang sesuai dengan hasrat belajar mereka. Hal 
ini tampak dengan adanya lomba atau kreativitas yang diikuti oleh siswa secara rutin melalui bimbingan guru di sekolah.

Selanjutnya sesuai dengan road map penelitian ini bahwa pelaksanaan pembelajaran sebelum dan setelah mengoptimalkan penggunaan perangkat pembelajaran maka akan dianalisis kemampuan berpikir kritis siswa melalui penggunaan soal Higher Order Thinking Skill (HOTS) dalam pembelajaran bahasa Indonesia terhadap prestasi belajar dan aktivitas belajar siswa. Dan hasilnya diketahui bahwa hasil belajar siswa sebelum dan sesudahnya mengalami peningkatan namun setelah diterapkannya pembelajaran jarak jauh (daring dan luring) ada sedikit penurunan dari hasil belajar siswa. Sebagaimana telah dijelaskan sebelumnya bahwa hal ini dapat terjadi akibat sistem belajar yang berubah, ditambah lagi dengan kemampuan siswa yang beragam. Sedangkan aktivitas belajar siswa tampaknya mengalami peningkatan yang cukup signifikan, dengan adanya ketrampilan berpikir kritis siswa, maka siswa semakin mengetahui karakter belajarnya dan hasrat belajar yang telah dimiliki. Artinya, siswa semakin memahami potensi yang dimilikinya melalui aktivitas yang dieksplorasi melalui kemampuan berpikir kritis terhadap soal-soal yang telah disusun oleh guru.

\section{E. KESIMPULAN}

Berdasarkan hasil analisis data pada bab III maka dapat disimpulkan bahwa:

1. Berdasarkan hasil tes, dapat diketahui bahwa $36 \%$ siswa nilainya di bawah KKM dan sekitar 64\% siswa nilainya diatas KKM. Hasil ini juga menunjukkan bahwa hasil belajar kelas ini baik, mengingat Kriteria Ketuntasan Minimal (KKM) Bahasa Indonesia yang digunakan oleh guru adalah 70.

2. Berdasarkan hasil angket, dapat diketahui bahwa $36 \%$ siswa kurang menyadari pentingnya berpikir kritis dalam mengikuti pelajaran Bahasa Indonesia. Hal ini menunjukkan bahwa aktivitas belajar siswa akan semakin kondusif jika guru mengajar sesuai dengan RPP (perangkat pembejaran).

3. Hasil angket juga menunjukkan bahwa hanya 64\% siswa yang menyadari pentingnya berpikir kritis selama mengikuti aktivitas belajar yang diselenggarakan oleh guru.

4. Berdasarkan data ini dapat diketahui bahwa aktivitas belajar siswa dan kemampuan berpikir kritis siswa masing-masing masih menunjukkan adanya ketidakseimbangan walaupun guru sudah mengoptimalkan fungsi perangkat pembelajaran dalam pengajarannya. 


\section{F. Saran}

Berdasarkan hasil penelitian yang telah diperoleh tim peneliti pada siswa di SMP TALITAKUM Medan tahun pelajaran 2019/2020. Maka berikut ini peneliti memberikan saran sebagai berikut:

1. Disarankan bagi para guru bahasa Indonesia agar semakin memotivasi siswa dalam pembelajaran. Agar siswa juga semakin terampil dan semakin kritis dalam setiap pembelajaran yang diberikan sesuai dengan kebutuhan pengetahuan yang dibutuhkan pada saat ini.

2. Guru semakin giat memberikan soal yang dapat mengasah keterampilan berpikir kritis siswa, terutama dalam pembelajaran bahasa Indonesia. Dan mengupayakan adanya media sharing seperti website sekolah, group sosmed, atau pertemuan reguler untuk meningkatkan keterampilan berpikir kritis siswa di sekolah maupun didalam kelas.

\section{DAFTAR PUSTAKA}

Depdiknas. 2007. Pedoman Pembelajaran Permainan Berhitung Pemulaan Di Taman Kanak- kanak. Jakarta: Dirjen Dikdasdem Indonesia, U. P. , \& UNPRI M. (2019, March). PROSIDING SEMINAR NASIONAL FAKULTAS KEGURUAN DAN ILMU PENDIDIKAN. In SEMINAR NASIONAL UNPRI (Vol.1, No.1).

Kurniati Dian, dkk. 2016. Kemampuan Berpikir Tingkat Tinggi Siswa SMP di Kabupaten Jember dalam Menyelesaikan Soal Berstandar Pisa (Vol.20, No.2). Jawa Timur, Jember: UNEJ.

Moleong, Lexy J. 2007. Metode Penelitian Kualitatif. Bandung: PT Remaja Rosdakarya

Pardede, O. B., \& Ariga, H. P. S. 2018. Analisis Faktor-Faktor Kendala Penulisan Karya Tulis Ilmiah dan Dampaknya terhadap Motivasi Meneliti oleh Guru di SMP seKecamatan Medan Selayang.

Pardede, O. B. 2019. Analisis Faktor Kendala-Kendala Dalam Penulisan Karya Tulis Ilmiah Dan Dampaknya Terhadap Motivasi Menulis Siswa Smp Di Kota Medan Tahun Pelajaran 2018-2019. Medan

Pardede, O. B. 2019. Eksperimentasi Penerapan Analisis SWOT dalam Merumuskan Strategi "Pemasaran" Professional Pendidik melalui Motivasi Kerja. Bahasa Indonesia Prima (BIP), 1(2), 7-14.

Pardede, O. B. 2019. Pengaruh Model Pembelajaran Terhadap Hasil Belajar Puisi Oleh Siswa Kelas Viii Smp Negeri 19 Medan Tahun Pelajaran 2018/2019. Medan

Pardede, O.B. 2019. Prosiding Seminar Nasional - Pembelajaran Bahasa dan Sastra Indonesia Berbasis HOTS Menuju Revolusi Industri 4.0. Medan: Balai Bahasa Sumatera Utara 
Salam, M. S. 2019. Penyusunan Soal Hots Guru Bahasa Indonesia Smp Negeri Di Kota Tulungagung. Malang: Pascasarjana UNISMA.

Simanullang, L. M., Purba, R. I., Bancin, N., \& Pardede, O. B. 2019. Pengaruh Model Pembelajaran Jigsaw dan Stad Terhadap Hasil Belajar Puisi Pada Siswa Kelas Viii Smp Negeri 19 Medan Tahun Pelajaran 2018/2019. EduTech: Jurnal Ilmu Pendidikan dan Ilmu Sosial, 5(2).

Siregar, G. H., Marpaung, S., Pardede, O. B., Kurnia, A. D., \& Butar-butar, Y. C. 2019. Eksperimentasi Kecerdasan Emosional Siswa Terhadap Pembelajaran Bahasa Indonesia Oleh Siswa Kelas VIII SMP Talitakum Tahun Pelajaran 2018/2019. EduTech: Jurnal Ilmu Pendidikan dan Ilmu Sosial, 5(2).

Sugiyono. 2011. Data kuantitatif adalah data yang berbentuk angka, atau data kualitatif yang diangkakan. Bandung.

Sugiyono. 2011. Metode Penelitian kualitatif, kuantitatif, dan R\&D. Bandung: ALFABETA.

Sugiyono. 2008. Metode Penelitian Pendidikan. Bandung: AlfaBeta.

Yuliandini Nurul, dkk. 2019. Pedadidaktika: Jurnal Ilmiah Pendidikan Guru Sekolah Dasar. Pengembangan Soal Tes Berbasis Higher Order Thinking Skill (Hots) Taksonomi Bloom Revisi di Sekolah Dasar (Vol.6, No.1). Tasikmalaya. 